\title{
POTENSI USAHA PEMBUATAN TERASI IKAN DI DESA TUNAS JAYA KECAMATAN POPAYATO BARAT KABUPATEN PAHUWATO
}

\author{
The Potential Of Making Businesses Fish Faste In Tunas Jaya Village, \\ Popayato Barat Subdistrict, Pahuwato District \\ Sudirman ${ }^{1)}$, Ardiansyah2) \\ ${ }^{1}$ Program Studi Pendidikan Ekonomi, Fakultas Ekonomi Universitas Negeri Gorontalo \\ ${ }^{2}$ Program Studi Pendidikan Ekonomi, Fakultas Universitas Negeri Gorontalo \\ Email: sudirman@ung.ac.id ${ }^{1)}$
}

\begin{abstract}
ABSTRAK
Potensi sumber daya alam Desa Tunas Jaya meliputi hasil pertanian dan kelautan. Masyarakat Desa Tunas Jaya sebagain berprofesi sebagai petani dan nelayan. Pendapatan masyarakat masih sangat tergantung pada musim iklim dan masyarakat masih banyak memiliki taraf ekonomi rendah. Masyarakat pada umumnya belum dapat memaksimalkan potensi sumber daya alam sekitar desa .Seperti pengolah ikan menjadi terasi. Kegiatan pengabdian KKN di desa Tunas Jaya merupakan upaya membantu masyarakat dalam memanfaatkan potensi ikan yang ada menjadi bahan bumbu masak yaitu terasi ikan. Kegitan ini berupa penyuluhan, pelatihan dan pendampingan secara berkala dan berkelanjutan untuk membentuk usaha produktif terasi ikan. Melalui pemberdayaan ini, masyarakat dapat dibelajarkan keterampilan dalam memilih bahan baku dan cara pembuatan terasi ikan, ketermapilan pengawetan terasi tanpa bahan kimia, pengemasan samapai pemasaran produk terasi ikan. Metode pelaksanaan program KKN ini berupa 1) Sosialisasi kegiatan pengembangan potensi desa, 2) pembentukan kelompok usaha, 3) pelatihan pengolahan terasi ikan, 4) Pengolahan Terasi ikan Secara Mandiri Oleh Masyarakat, 5) Pengolahan Terasi ikan Secara Mandiri Oleh Masyarakat, 6) Pelatihan Kewirausahaan.7) monitoring dan evaluasi kegiatan. Kegiatan ini bertujuan untuk mengembangkan krativitas masyarakat dalam mengembangkan potensi alam yang ada seperti pengelahan ikan menjadi terasi. Hasil dari pengabdian ini adalah terciptanya tenaga lokal yang potensial untuk mengelola sumberdaya sekitarnya menjadi usaha produktif.
\end{abstract}

\section{Kata kunci: Pengolahan Ikan; Terasi}

\begin{abstract}
The potential natural resources of Tunas Jaya Village include agricultural and marine products. The people of Tunas Jaya Village, in part, work as farmers and fishermen. Community income is still very dependent on the climate season and many people still have low economic levels. The community in general has not been able to maximize the potential of natural resources around the village, such as processing fish into shrimp paste. The Community Service Program in Tunas Jaya Village is an effort to assist the community in utilizing the potential of the existing fish into cooking spices, namely fish paste. This activity is in the form of regular and continuous counseling, training and mentoring to form a productive business of fish paste. Through this empowerment, the community can learn the skills in choosing raw materials and how to make fish paste, how to preserve shrimp paste without chemicals, packaging and marketing of fish paste products. The method of implementing this KKN program is in the form of 1) Socialization of village potential development activities, 2)
\end{abstract}


establishment of business groups, 3) training on processing fish paste, 4) Processing of fish paste independently by the community, 5) Processing of fish paste independently by the community, 6) Training Entrepreneurship. 7) monitoring and evaluation of activities. This activity aims to develop the community's creativity in developing existing natural potentials such as processing fish into shrimp paste. The result of this dedication is the creation of potential local workers to manage the surrounding resources into productive businesses

Keywords: Fish Processing; Terasi

\section{PENDAHULUAN}

Desa Tunas Jaya yang memiliki sumber daya alam dari hasil pertanian dan perikanan yang bagus. Mata Pencaharian utama masyarakat Tunas Jaya adalah petani dan nelayan. Sebagian besar berprofesi sebagai petani dan sebagian lagi berprofesi sebagai nelayan. Desa tunas jaya berada pada dataran tinggi dan juga dekat dengan pantai. Potensi pengembangan sumber daya perikanan belum dikembangkan dengan maksimal sehingga belum dapat memberikan sumbangsi bagi perekonomian masyarakat dasa Tunas Jaya. Hasil perikanan yang cukup banyak dan belum ada upaya usaha pengelolahan ikan menjadi barang siap komsumsi menjadi permasalahan terhadap hasil tangkapan nelayan.

Indonesia merupakan negara maritim. Sebagian besar wilayah Indonesia terdiri dari lautan. Lautan di wilayah Indonesia kaya berbagai jenis ikan. Sumber daya alam laut berupa biota laut, tambang minyak lepas pantai dan pasir besi. Potensi ikan laut Indonesia mencapai 6 juta ton per tahun. Potensi laut Indonesia berada di urutan keempat pada 2009 di dunia (Sutrisni, 2020).

Upaya pengembangan dari sektor perikanan juga sangat penting dalam meningkatkan kesejahtraan masyarakat, meningkatkan ekonomi dan gizi masyarakat. (Wawansyah dkk, 2012). Salah satu usaha pengloahan hasil perikanan yaitu pembuatan terasi. Pembuatan terasi ikan merupakan salah satu alternatif yang dilakukan oleh masyarakat pesisir untuk mengantisipasi ikan menjadi busuk karena masa simpannya yang pendek (Purtomo et al., 2016). Terasi merupakan produk awetan ikan-ikan kecil atau rebon yang telah diolah melalui proses fermentasi (Pasta et al., 2014). Fermentasi adalah penguraian senyawa lemak dan protein kompleks yang terdapat dalam tubuh ikan menjadi senyawa yang lebih sederhana dengan bantuan enzim dari mikroba fermentor (Dan Dewa Ayu Citra Rasmi, 2014).

Salah satu upaya peningkatan ekonomi masyarakat yaitu dengan pemberdayaan usaha kecil dan menengah (UMKM) (Jauhari, 2010). Salah satu usaha kecil dan menengah UMKM yaitu pengelohan hasil perikanan berupa pembuatan terasi ikan yang memiliki nilai ekonomis.

Usaha pembuatan terasi ikan mejadi objek dalam pengabdian masyarakat KKN Tematik 2020 di Desa Tunas Jaya. Upaya yang dilakukan dengan memberikan pelatihan kepada msyaratakat tentang pembuatan terasi ikan.

\section{SOLUSI DAN TARGET LUARAN}

\section{Solusi Permasalahan}

Upaya untuk mengurangi dampak pembusukan pada hasil tanggapan ikan maka dapat dilakukan melalui proses fermentasi berupa pembuatan terasi dari ikan.

Melalui kegiatan pelatihan
pembuatan terasi ikan dengan memanfaatkan potensi sumber daya yang ada berupa hasil tanggapan ikan yang ada di 
desa Tunas Jaya dapat dimanfaatkan sebaikbaiknya oleh masyarakat setempat dengan cara membentuk kelompok usaha kecil pembuatan terasi ikan.

Pembekalan dan pemberian materi mengenai pemilihan bahan baku ikan, kandungan gizi dan manfaat terasi kepada masyarakat desa Tunas Jaya sangat penting bagi sebagai bekal pengetahuan dalam pelatihan tersebut.

Hal ini mampu memberikan manfaat kepada masyarakat yang memiliki kesadaran dalam mengelola usaha untuk memperoleh pendapatan yang layak serta meningkatnya jiwa kewirausahaan dan pengetahuan pembuatan terasi ikan.

\section{Luaran dan Target Capaian}

Adapun target luaran yang akan dicapai pada kegiatan Pelatihan ini adalah:

1. Menumbuhkan kesadaran, minat, pengetahuan dan keterampilan kepada masyarakat dalam memanfaatkan hasil tanggapan ikan yang melimpah.

2. Memanfaatkan ikan menjadi produk terasi yang bernilai ekonomis yang dapat menjadi peluang usaha masyarakat

3. Meningkatkan kesadaran masyarakat dalam mengelola usaha pembuatan terasi ikan untuk memperoleh pendapatan yang layak serta meningkatkan jiwa kewirausahaan dan pengetahuan masyarakat desa Tunas Jaya.

\section{METODE PELAKSANAAN KEGIATAN}

Pada kegiatan pelaksanaan pelatihan ini akan didampingi langsung oleh tim Pelatihan yaitu narasumber selama proses pendampingan saat pelatihan pembuatan terasi dari ikan.

Metode pelaksanaan dari kegiatan ini antara lain sosialisasi pengembangan potensi sumber daya alam desa, pembentukan kelompok usaha, pelatihan pengolahan terasi ikan, pengolahan terasi ikan secara mandiri oleh masyarakat, pelatihan kewirausahaan, monitoring dan evaluasi kegiatan.

\section{HASIL DAN PEMBAHASAN}

Hasil dari pelaksanaan Pelatihan pembuatan terasi ikan di desa Tunas Jaya, Kecamatan Popayato Barat Kabupaten Pahuwato adalah sebagai berikut:

1. Sosialisasi Kegiatan Pengembangan Potensi Desa

Kegiatan ini dilakukan dengan mengadakan seminar dan sosilaisasi kepada masyarakat tentang potensi daerah yang dapat di optimalkan dalam rangka meningkatkan ekonomi masyarakat. Memberikan pemahaman kepada masyarakat tentang upaya yang dapat dilakukan dalam mengolah potensi sumber daya alam berupa hasil pertanian dan hasil laut menjadi barang siap komsusi ataupun menjadi barang hasil olahan yang memiliki nilai jual tinggi. Seperti mengolah ikan menjadi terasi ikan.

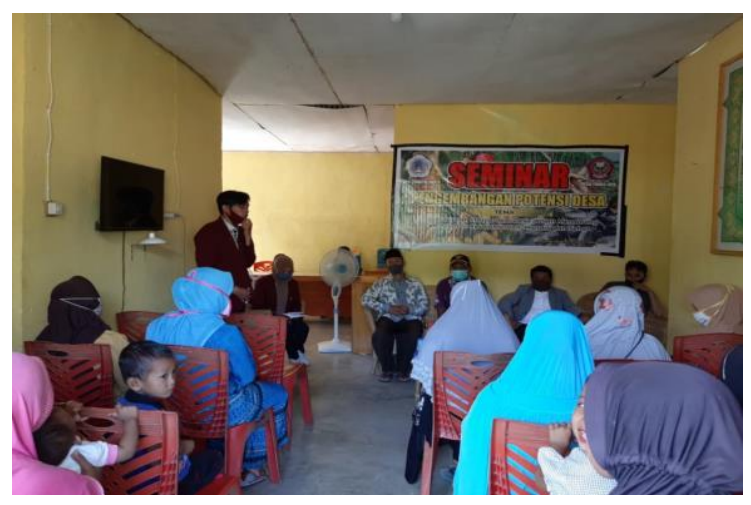

Gambar 1. Suasana saat seminar dan sosialisasi potensi sumbur daya alam desa

2. Pembentukan Kelompok Usaha Pembuatan kolompok usaha dilakukan untuk memudahkan dalam kordinasi dan kerjasama dalam pembuatan terasi ikan. Kelompok usaha dibentuk dari Ibu-ibu rumah tangga. Kelompok ini diberi nama 
"Tunas Jaya (TJ)" dan dibuat struktur organisasi terdiri dari ketua kelompok, Bendahara, dan agen pemasaran yang memiliki tugas dan tanggung jawab masingmasing. Pembentukan kelompok usaha ini bertujuan untuk memudahkan pengolah terasi ikan, pemasaran produk, serta mengatasi permasalahan-permasalahan yang muncul secara bersama- sama.

\section{Pelatihan Pengolahan Terasi Ikan}

Kegiatan ini dilakukan dengan mengundang masyarakat untuk melihat dan menyaksikan proses pembuatan terasi. Dalam pelatihan ini juga mengajak sebagaian masyarakat untuk terlibat langsung dalam proses pembuatan terasi ikan. Pada pelatihan itu juga masyarakat diberikan tips serta saran mengenai cara memilih bahan ikan yang baik sampai terasi itu di kemas.

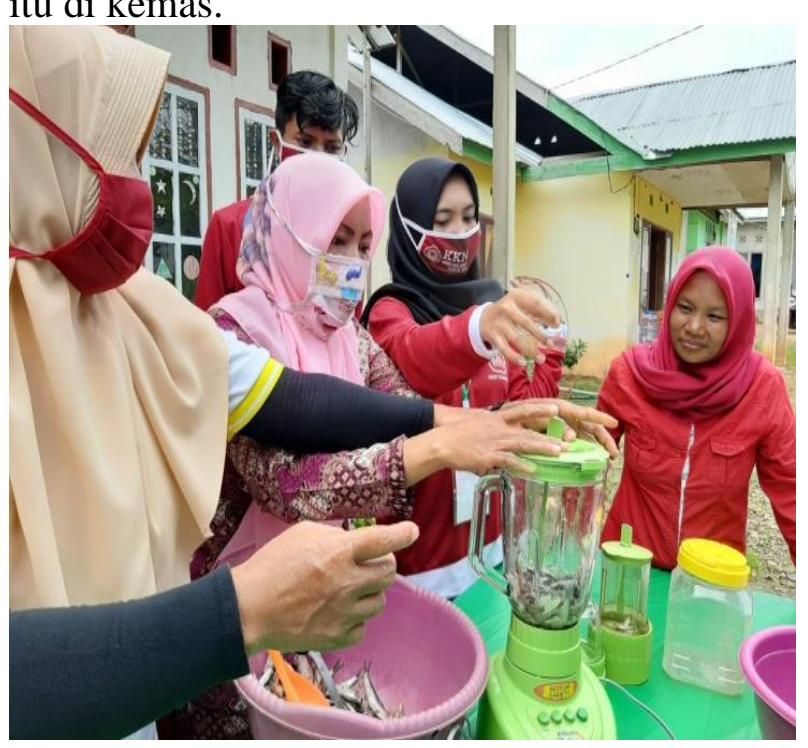

Gambar 2. Masyarakat dan mahasiswa saling bekerja sama mengolah ikan menjadi terasi

\section{Pengolahan Terasi ikan Secara Mandiri Oleh Masyarakat}

Pengolahan terasi ikan dilakukan secara mandiri oleh masyarakat dilakukan untuk memastikan bahwa masyarakat benarbenar menguasai pengolahan terasi ikan yang sudah diberikan. Dari monitoring dan evaluasi yang dilakukan ternyata masyarakat sudah benar-benar menguasai pengolahan terasi ikan mulai penyiapan bahan baku, proses pengolahan, proses pengemasan hingga pemasaran..

\section{Pelatihan Kewirausahaan}

Pelatihan ini dilakukan untuk pembentukan karakter wirausahawan dan peningkatan kemampuan berwirausaha. Dimulai dari membangun motivasi menjadi wirausahawan, membentuk karakter dan mental seorang pengusaha, serta giat dalam menjalankan usaha. Kegiatan ini juga dilakukan untuk mencari dan menentukan pasar dan harga jual. Kegitan ini diharapkan agar kegiatan ini dapat terus dikembangkan dan produksinya dapat ditingkatkan seiiring dengan kemampuan masyarakat dalam menjalankan usahanya.

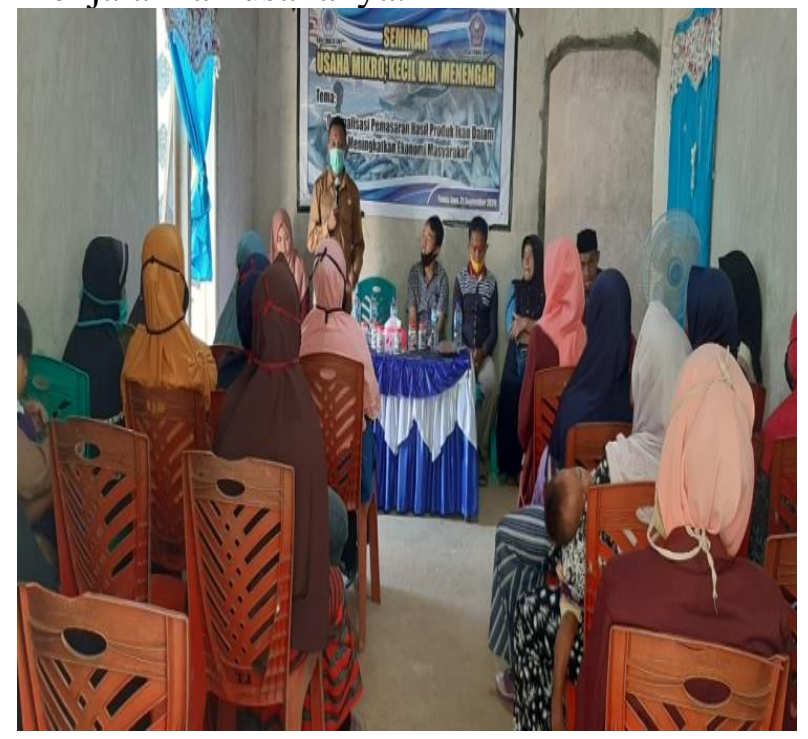

Gambar 3. Dosen pendamping lapangan dan mahasiswa memberikan arahan untuk peningkatan karakter berwirausaha.

\section{Monitoring dan evaluasi kegiatan} KKN.

Evaluasi kegiatan ini dilakukan oleh dosen pembimbing lapangan 1 kali dalam 2 minggu untuk mengetahui bagaimana keberlangsungan dan kemajuan dari kegiatan yang dilakukan, selain itu membahas berbagai masalah dan kendala yang mungkin terjadi di lapangan untuk menemukan solusi yang tepat serta melakukan pendampingan terhadap masalah 
atau kendala di tengah masyarakat selama pelaksanaan kegiatan KKN.

\section{KESIMPULAN DAN SARAN}

Kegiatan ini meliputi beberapa tahap kegiatan diantara: sosialisasi pengembangan potensi sumber daya alam desa, pembentukan kelompok usaha, pelatihan pengolahan terasi ikan, pengolahan terasi ikan secara mandiri oleh masyarakat, pelatihan kewirausahaan, monitoring dan evaluasi kegiatan. Hasil dari Program kegiatan inti tercapai dalam aspek menciptakan produk bernilai konsumtif dan ekonomis. Kegiatan pelatihan ini memberikan peluang terciptanya tenaga lokal yang potensial untuk mengelola sumberdaya sekitarnya menjadi usaha produktif seperti terasi ikan.

\section{UCAPAN TERIMAKASIH}

Penulis mengucapkan terima kasih kepada Bapak Ma`Rif Setiawan F.Biki selaku Kepala Desa Tunas Jaya, aparat desa Tunas Jaya serta masyarakat desa Tunas Jaya atas partisipasi dan dukungannya dalam pelaksanaan kegiatan ini. Sehingga kegiatan ini dapat terlaksana dengan baik dan lancar.

\section{DAFTAR PUSTAKA}

Dan Dewa Ayu Citra Rasmi, Y. F. A. S. (2014). Fermentasi Ikan Kembung (Rastrelliger sp.) dalam Pembuatan Peda dengan Penambahan Bakteri Asam Laktat (BAL) yang Terkandung dalam Terasi Empang pada Berbagai Konsentrasi Garam. Jurnal Biologi Tropis, 14(2). https://doi.org/10.29303/jbt.v14i2.142

Jauhari, J. (2010). Upaya Pengembangan Usaha Kecil dan Menengah (UMKM) dengan Memanfaatkan E-Commerce. Jurnal Sistem Informasi, 2(1), 159168.

https://ejournal.unsri.ac.id/index.php/j si/article/view/718

Pasta, K., Ikan, D., Tawar, A. I. R., \& Laut, P. D. A. N. (2014). PENGARUH PERBEDAAN BAHAN BAKU TERHADAP KANDUNGAN ASAM GLUTAMAT PADA TERASI. 3(2003), 75-81.

Purtomo, T., Aju, I., Ratih, B., Utomo, D. B., Ekonomi, F., \& Psikologi, F. (2016). IbM KELOMPOK USAHA RUMAH TANGGA TERASI REBON. Jurnal Pengabdian LPPMUntag Surabaya, 02(01), 19-28.

Sutrisni, A. (2020). Potensi sumber daya alam indonesia. Kompas.

Wawansyah dkk. (2012). KONTRIBUSI EKONOMI PRODUKTIF WANITA NELAYAN TERHADAP PENDAPATAN KELUARGA

NELAYAN. 3(2). 